Alfarama Journal of Basic \& Applied Sciences

Faculty of Science Port Said University

January 2021, Volume 2, Issue 1 https://ajbas.journals.ekb.eg

ajbas@sci.psu.edu.eg

http://sci.psu.edu.eg/en/

DOI:10.21608/ajbas.2020.37514.1027

Submitted: 04-08-2020

Accepted: 30-08-2020

Pages: 1-7

\title{
Evaluation Gene Expression of Kinase Insert Domain (KDR) as Prediction of Preeclampsia with Novel Biomarkers
}

\author{
Ibrahim M. EL-Deen ${ }^{1}$, Amal K. Seleem ${ }^{2}$, A. A. Abdel Aziz ${ }^{3}$, E. H. ELSayd ${ }^{4}$, Ateya G. Amin ${ }^{5, *}$ \\ ${ }^{1}$ Department of Chemistry, Faculty of Science, Port Said University, Port Said, Egypt. \\ ${ }^{2}$ Department of Clinical Biochemistry, Faculty of Medicine , Mansoura University, Mansoura, Egypt. \\ ${ }^{3}$ Department of Gynocology, Faculty of Medicine, Mansoura University, Mansoura, Egypt. . \\ ${ }^{4}$ Department of Chemistry, Faculty of Science, Port Said University, Port Said, Egypt. \\ ${ }^{5}$ Insurance of health, Central laboratories, Mansoura, Egypt. \\ *Corresponding author: attiagomaa72@yahoo.com
}

\begin{abstract}
Preeclampsia (PE) is the complexity the case of pregnancy with an indication of the presence of defective placentas, and inadequate blood supply to the placenta defect and endothelial dysfunction the aim of study. The variation between endothelial growth factor angiogenesis (VEGF), placental growth factor (PIGF) and their receptors kinase domain that contains the receptor (KDR) and tyrosine kinase 1 (Flt-1) plays a valuable role in the pathophysiology of PE .We conducted a cross-sectional study of 50 women with Preeclampsia: 25 women with mild $\mathrm{PE}$, and 25 patients with severe PE. While 24 pregnant women work normally with age as a control group. placental mRNA gene expression of KDR was measured using real time PCR ( RT/PCR),The mean of KDR expression was statistically significantly higher in the control group compared to any of the PE groups ( $\mathrm{p}<0.0005)$ and there was no statistically significant difference between sever PE and mild PE groups. The Information from different groups that reinforce KDR theory, useful in identifying an opportunity for ladies with Preeclampsia, to accurately diagnose Preeclampsia and anticipate progression of difficulties.
\end{abstract}

\section{Keywords}

Preeclampsia, KDR, endothelial dysfunction, placental ischemia.

\section{INTRODUCTION}

Preeclampsia is a pregnancy related illness that occurs in 5-8\% of pregnancy and is an important cause of disease and maternal mortality and fetus. The description of the disease symptoms of mothers that may occur from pregnancy for 20 weeks, high blood pressure> 140/90 mm Hg and proteinuria (> $300 \mathrm{mg} / 24$ hours) is also characterized by the Royal College of Obstetricians and Gynecologists [1].The exact cause of Preeclampsia confused, but it is known that this infection incited by placentas factor assumes that oxidative stress may participate equally in dentistry [2]. It is recognized that the primary component of PE hinders the placenta due to lack of infiltration trophoblast in the arteries winding motherly [3]. Lead expansion is full of 
the arteries of the placenta to the maternal lack of blood supply to the developing fetus [4]. It produces power ischemia and placental hypoxia [5].

A possible critical system of disease (PE) is a mismatch between the placenta proteins that generate the placenta and the antiangiogenic proteins. Proteins VGFC and PLGF are linked to the formation of blood guidelines for the growth of blood vessels choroid is expected to reduce maternal lining during pregnancy [6]. To regulate the vascular changes chorionic early, family can VEGF for vascular growth factors to do so. The intervention in improving VEGF systematically through the link receptors VEGFR-1, which are expressed in vascular endothelial cells in the trophoblast cells of the choroid in individual cells and large cells and KDR, which is surprising receptors that are expressed mainly in venous endothelial cells waiting for the exclusive development of new blood vessels [7].The current study aims to study the expression of KDR mRNA in the placenta of the breed vessels to link the degree of disruption of blood vessels with PE degree and gain further evidence of her job in Preeclampsia..

\section{SUBJECTS AND METHODS}

\subsection{Subjects}

Fifty patients determined to have PE were assembled from the Obstetrics and Gynecology division, Mansoura University, Egypt . Their mean age (years) \pm SD were $28.15 \pm 5.25$ ) during the period from July 2015 and May 2017. Preeclamptic women were partitioned into 25 women analyzed as mild preeclampsia (MPE), diagnosed as blood pressure $\geq 140 / 90 \mathrm{mmHg}$ and 25 women were analyzed as severe preeclampsia (SPE) ,diagnosed as blood pressure $\geq 160 / 110 \mathrm{mmHg}$. The control group included 24 normotensive pregnant women . Exclusion criteria included pregnancy twins, women who have a background characterized by diabetes, liver or kidney disease or a continuous rise in the previous blood pressure, which has no end integration criteria: Normotensive pregnant women had blood pressure less than 120/80 $\mathrm{mm} \mathrm{Hg}$ and there was no history of high blood pressure or proteinuria. Every pregnant woman referred to the gestational age of 20 to 40 weeks. Control group were taken from women who entered Mansoura University Hospital, Egypt, Obstetric department, Cohort study of mothers within two weeks of each case .Ethical approval: A composed educated assent was taken before test withdrawal. The examination was acted as per the moral guidelines set down in Mansoura Faculty of Medicine.

\subsection{Methods}

\subsubsection{Urine Collection:}

All pregnant women were asked for ten millilitres of urine for protein detection by dipstick in at least two random urine specimens obtained at least $4 \mathrm{~h}$ apart was required. proteinuria means protein $\geq 3 \mathrm{gr}$ in a 24 hr (medi-test combi).

\subsubsection{RNAextraction from placental tissue}

Fresh samples of 74 placentas humanity within 30 min after placental delivery, After a wash of the samples with normal saline were performed, the amniotic layers and the maternal decidua were removed, then the samples were snap frozen in liquid nitrogen and stored at -70C until RNA isolation by using miRNeasy mini kit (Qiagen, cat no. 217004, Germany). RNA was quantified by spectrophotometry [8]. we measured the expression of KDR gene in placenta by used TaqMan real-time PCR ((provided by Thermo Scientific, USA, cat No. \# K1641).

\subsubsection{Produce DNA from RNA by Reverse Transcription}

For each sample, was used $1 \mu$ gof total RNA Adjust by reverse transcription using the Maxima ${ }^{\circledR}$ First Strand cDNAsynthess kit provided by Thermo Scientific, USA, cat. No.K1641. Following the manufacturer's instructions, Reverse transcription and the quantitative PCR were performed as previously described[9,10]. 
Genetic prefixes own purchased from Invitrogen by Thermo Fisher Scientific. It was selected primer sets to amplify the gene PCR after three of the gene sequence database NCBI [11].,It included the following assay targeting specific mRNAs in the study: KDR: forward 5-GTAGGACTGCTCAGTTCAAACAT-3, reverse 5- ACAGTTACTACACCCGTAAGG-3.

\subsubsection{Quantitative PCR Analysis.}

PCR was performed in real-time serial to estimate the quantification of genes VEGF and Flt1 and KDR using SensiFAST SYBR ${ }^{\circ}$ Lo-ROX (purchased from Bioline, London, United Kingdom, Catalog Number: BIO-94005) following the manufacturer's instructions[12] .Analysis was performed fusion curve after amplification to confirm the product's privacy and exclude the presence Altmhedy-dimmers. Genetic expression was performed using the relative delta delta cycle threshold (DDCT)by using method $2-\Delta \Delta \operatorname{ct}[13-14]$.

\section{STATISTICAL ANALYSIS}

Data analysis was performed by Statistical package for social science software (SPSS) version 25. Data are presented as mean \pm SD and compared by One-Way ANOVA and they are presented as median (IQR) and compared by Kruskal-Wallis (K-W) test. Significance was considered at $\mathrm{P}<0.05$ [31]. Data are presented as frequency (percentage) and compared by Chi-Square test (Monte Carlo significance).**Data are presented as median (IQR) and compared by Kruskal-Wallis (K-W) test. Pairwise comparisons are presented as capital letters $($ similar letters $=$ no significant difference, while different letters $=$ significant difference).

\section{RESULTS}

This study involved 74 subjects divided into 3 groups: The first is control group: 24 pregnantwomen with no current or previous PE. Their mean age (years) $\pm \mathrm{SD}=27.8 \pm 4.7$ years. The second is $\mathrm{mPE}$ group: 25 pregnant ladies fulfilling the criteria of mPE. Their mean age was found to be $27.5 \pm 4.3$ years. The third is sPE group: 25 pregnant women fulfilling the criteria of sPE.Their mean age $\pm \mathrm{SD}=28.8 \pm 6.2$ years. There was statistically significant difference in the level of protein in urine with trace and + in mild cases, but ++ and +++ in severe cases $(\mathrm{P}<0.0005)($ Table 1$)$.

Table(1):Comparison of proteinuria and previous Preeclampsia between mild and severe Preeclampsia.

\begin{tabular}{|c|c|c|c|c|}
\hline \multirow[b]{2}{*}{ Variable } & \multicolumn{2}{|c|}{ Group } & \multirow[b]{2}{*}{ Statistic } & \multirow[b]{2}{*}{$P$ value } \\
\hline & $\begin{array}{l}\text { Mild PE } \\
(n=25)\end{array}$ & $\begin{array}{c}\text { Severe PE } \\
(n=25)\end{array}$ & & \\
\hline $\begin{array}{ll}\text { Protein } & \text { in } \\
\text { urine: } & \\
\text { Nil } & \\
\text { Trace } & \\
+ \\
++ \\
+++\end{array}$ & $\begin{array}{c}1(4 \%) \mathrm{a} \\
13(52 \%) \mathrm{a} \\
11(44 \%) \mathrm{a} \\
0(0 \%) \mathrm{a} \\
0(0 \%) \mathrm{a}\end{array}$ & $\begin{array}{c}0(0 \%) \mathrm{a} \\
0(0 \%) \mathrm{b} \\
0(0 \%) \mathrm{b} \\
12(48 \%) \mathrm{b} \\
13(52 \%) \mathrm{b}\end{array}$ & $\chi^{2}=50.000$ & $\begin{array}{c}* *<0.00 \\
05\end{array}$ \\
\hline
\end{tabular}

**Data are presented as median (IQR) and compared by Kruskal-Wallis (K-W) test. Pairwise comparisons are presented as capital letters ( difference). **Data are presented as median (IQR) and compared by Kruskal-Wallis (K-W) test. Pairwise comparisons are presented as capital letters (similar letters $=$ no significant difference, while different letters = significant difference). 
KDR is the major mediator of migration, proliferation and differentiation of endothelial cells. Activation of KDR results in an expansion in both mitogenic cell signaling and migratory activity of endothelial cells[15]. The present study showed that, KDR expression was statistically significantly higher in control group as compared to either of the two PE groups $(\mathrm{p}<0.0005)$ and there is no statistically significantly difference between SPE and mPE (Table 2). Our studywas consistent with numerous studies which indicated that the KDR expression is low in pregnancies comlicated by PE than control[16-19, 24].Other studies, have detailed additional levels of maternal plasma from sKDR during PE or early pregnancy while reducing intrauterine growth [20-22].

George et al., stated that the expression of KDR is low in PE women result from the decline in access to free VEGF to stimulate the synthesis of KDR and move away from the cell surfaces of endothelial cell surfaces, as seen in other models [23]. PE is characterized by the destroying of the motherly vessels that call for the failure of the placenta, which in turn are associated with high speed in the mother's blood flow to the chorionic villi, however, changes in the composition of vessels within the placenta in any case questionable [25].It is expected to improve the increase in vessels, which were seen in the villi separated from the preeclamptic placenta, to facilitate the transfer of oxygen supplementation between the mother and the fetus [15].

Table (2): Comparison of the KDR between the three study groups

\begin{tabular}{|c|c|c|c|c|c|}
\hline \multirow[b]{2}{*}{$\begin{array}{c}\text { Variabl } \\
\mathrm{e}\end{array}$} & \multicolumn{3}{|c|}{ Group } & \multirow[b]{2}{*}{ Statistic } & \multirow[b]{2}{*}{$P$ value } \\
\hline & $\begin{array}{l}\text { Control } \\
(n=24)\end{array}$ & $\begin{array}{l}\text { Mild PE } \\
(n=25)\end{array}$ & $\begin{array}{c}\text { Severe PE } \\
(\mathrm{n}=25)\end{array}$ & & \\
\hline KDR & $\begin{array}{c}1.28 \pm 0.13 \\
\mathrm{~A}\end{array}$ & $\begin{array}{c}0.61 \pm 0.23 \\
B\end{array}$ & $\begin{array}{c}0.61 \pm 0.24 \\
\text { B }\end{array}$ & $\begin{array}{c}F= \\
86.265\end{array}$ & $*<0.0005$ \\
\hline
\end{tabular}

Data are presented as median (IQR) and compared by Kruskal-Wallis (K-W) test. Pairwise comparisons are presented as capital letters $($ similar letters $=$ no significant difference, while different letters = significant difference). **Data are presented as median (IQR) and compared by Kruskal-Wallis (K-W) test. Pairwise comparisons are presented as capital letters (There was no significant differences between means have the same letter, while different letters $=$ significant difference) .

Vessels exceed the development of the growth medium villi mature, blood and turn into circles and wrapped structure, which spread from the average surface villi mature, to form a new terminal villi [26].However, it has been assumed that a greater number of vessels in the villi, may reduce the diffusion of oxygen in the placenta, due to diffuse examination [15]. This decrease in oxygen conductivity is manifested by an increase in the placental hypoxia factor in PE [27]. These lines make sense to increase the placenta formation in the placenta before sagging, most likely not distinguishing the fetus. It is also plausible that increased vascular formation is not sufficient to overcome both the reduced oxygen conduction caused by the placenta infarction and the expected decrease in oxygen delivery while reshaping the maternal spiral arteries that provide the overlapping space [28]. In a few investigations there is no qualification in the expression of KDR mRNA between PE and controls [28-30].

The biomarker KDR with other angiogenic factors which may have ability to investigation and diagnosis of severe-early onset PE but couldn't be utilized alone for intervention, but in conjunction with other angiogenic factors like soluble endoglin, Doppler sonography and other clinical and biochemical biomarkers they are progressively important for predicting. 


\section{CONCLUSION}

Overall, though, we found a significant decrease in KDR mRNA expression in the placenta for two preeclampsia groups compared to the Normotensive women's group, Further studies are needed to understand the molecular defect in preeclampsia and the role of KDR biomarker for diagnosis, prognosis and treatment of this obstetric condition.

\section{ACKNOWLEDGEMENT}

We are extremely grateful for all the women who contributed to the study and their families and medical staff in the Department of Obstetrics and Gynecology at the hospital.The authors would like to thank both help us and support us.

\section{REFERENCES}

[1] STEEGERS EA, VON DADELSZEN P, DUVEKOT JJ, PIJNENBORG R. Pre-eclampsia. Lancet; 376:631-644, (2010).

[2] CHEN Q, JONES D, STONE P, CHING LM, CHAMLEY L. Vitamin C enhances phagocytosis of necrotic trophoblasts by endothelial cells and protects the phagocytosing endothelial cells from activation. Placenta; 30:163-168, (2009).

[3] PLASENCIA W, MAIZ N, BONINO S, KAIHURA C, NICOLAIDES KH. Uterine artery Doppler at $11+0$ to $13+6$ weeks in the prediction of pre-eclampsia. Ultrasound ObstetGynecol; 30:742749, (2007).

[4] BASUNI, M., FATHY W, GABER W. Assessment of placental growth factor and soluble vascular endothelial growth factorreceptor 1 in the prediction of pre-eclampsia. Egypt. J. Haematol., 37, 4, $281,(2012)$

[5] SOLEYMANLOU N, JURISICA I, NEVO O, IETTA F, ZHANG X, ZAMUDIO S, ET AL.Molecular evidence of placental hypoxia in preeclampsia. J ClinEndocrinolMetab; 90:42994308, (2005).

[6] SAVVIDOU MD, NOORI M, ANDERSON JM, HINGORANI AD, NICOLAIDES KH. Maternal endothelial function and serum concentrations of placental growth factor and soluble endoglin in women with abnormal placentation. Ultrasound ObstetGynecol ; 32:871-876, (2008).

[7] KIM JY, WHANG JH, ZHOU W, SHIN J, NOH SM, SONG IS, ET AL. The expression of VEGF receptor genes is concurrently influenced by epigenetic gene silencing of the genes and VEGF activation. Epigenetics; 4: 313-321, (2009).

[8] MACFARLANE E. AND DAHLE C. E.: Isolating RNA from whole blood--the dawn of RNAbased diagnosis?\| Nature; 362(6416): 186-188, (1993).

[9] SAMBROOK J., FRITSCHI E. F. AND MANIATIS T.: Molecular cloning: a laboratory manual, Cold Spring Harbor Laboratory Press, New York, NY, USA, (1989).

[10] FREEMAN W. M., WALKER S. J., AND VRANA K. E.: Quantitative RT-PCR: pitfalls and potential,\| Biotechniques; 26(1): 112-122, (1999).

[11] SAIKI R. K., GELFAND D. H. AND STOFFEL S.: Primer-directed enzymatic amplification of DNA with a thermostable DNA polymerase, $\|$ Science; 239(4839): 487-491, (1988).

[12] COULOURIS J., YE G. I. AND ZARETSKAYA I.: CUTCUTACHE, S. ROZEN, AND T. MADDEN, PRIMER-BLAST: a tool to design target-specific primers for polymerase chain reaction, BMC Bioinformatics; 13(134), (2012).

[13] HIGUCHI R., FOCKLER C., DOLLINGER G. AND WATSON R.: Kinetic PCR analysis: realtime monitoring of DNA amplification reactions, Nature Biotechnology; 11(9): 1026-1030, (1993). 
[14] LIVAK K. J. AND SCHMITTGEN T. D.: Analysis of relative gene expression data using real-time quantitative PCR and the 2- $\triangle \Delta C T$ method,,$\|$ Methods; 25(4): 402-408, (2001).

[15] GILLE H., KOWALSKI J., LI B., LE COUTER J., MOFFAT B., ZIONCHECK TF, PELLETIER N. AND FERRARA N.: Analysis of biological effects andsignaling properties of Flt-1 (VEGFR-1) and KDR (VEGFR-2).A reassessment using novel receptor-specific vascular endothelial growth factor mutants. J BiolChem; 276: 3222-3230, (2001).

[16] ANDRAWEERA PH, DEKKER GA, LAURENCE JA AND ROBERTS CT.: Placental expression of VEGF family mRNA in adverse pregnancy outcomes. Placenta; 33: 467-472, (2012).

[17] MARINI M., VICHI D., TOSCANO A., THYRION GZ, PARRETTI E. AND MELlO G.: Expression of vascular endothelial growth factor receptor types 1, 2 and 3 in placenta from pregnancies complicated by hypertensive disorders. ReprodFertilDev; 19: 641-651, (2007).

[18] GROTEN T., GEBHARD N., KREIENBERG R., SCHLEUSSNER E., REISTER F. AND HUPPERTZ B.: Differential expression of VE-cadherin and VEGFR-2 in placental syncytiotrophoblast during preeclampsia- New perspectives to explain the pathophysiology. Placenta; 31: 339-343, (2010).

[19] AGARWAL RACHNA, NEELAMKUMARI, RAJARSHIKAR, NILESH CHANDRA AND ARCHANANIMESH: Evaluation of Placental VEGFA mRNA Expressionin Preeclampsia: A Case Control Study. Federation of Obstetric \& Gynecological Societies of India; 68(2): 88-95, (2018).

[20] MUNAUT C., LORQUET S., PEQUEUX C., COULON C., LE GOARANT J. AND CHANTRAINE F.: Differential expression of Vegfr-2 and its soluble form in preeclampsia. Plos One; 7: e33475, (2012).

[21] SAHAY AKRITI S., VIDYA V. PATIL, DEEPALI P. SUNDRANI, ASMITA A. JOSHI1, GIRIJA N. WAGH, SANJAY A. GUPTE AND SADHANA R. JOSHI1,: A longitudinal study of circulating angiogenic and antiangiogenic factors and AT1-AA levels in preeclampsia. Hypertension Research; 37: 753-758, (2014).

[22] TRIPATHI R., RATH G., RALHAN R., SAXENA S. AND SALHAN S.: Soluble and membranous vascular endothelial growth factor receptor-2 in pregnancies complicated by pre-eclampsia. Yonsei Med J; 50: 656-666, (2009).

[23] GEORGE M., RAINEY MA, NARAMURA M., FOSTER KW AND HOLZAPFEL MS,: Renal thrombotic microangiopathy in mice with combined deletion of endocytic recycling regulators EHD3 and EHD4. PLoS One; 6: e17838, (2011).

[24] ALI ZAIMA, SABA KHALIQ, SAIMAZAKI, HAFIZ USMAN AHMAD AND KHALID PERVAIZ LONE: Differential Expression of Placental Growth Factor, Transforming Growth Factor- $\alpha$ and Soluble Endoglin in Peripheral Mononuclear Cells in Preeclampsia Journal of the College of Physicians and Surgeons Pakistan; 29(3): 235-239, (2019).

[25] BURTON GJ, YUNG HW, CINDROVA-DAVIES T. AND CHARNOCK-JONES DS,: Placental endoplasmic reticulum stress and oxidative stress in the pathophysiology of unexplained intrauterine growth restriction and early onset preeclampsia. Placenta; 30: 43-48, (2009).

[26] KARIMU AL AND BURTON GJ.: Significance of changes in fetal perfusion pressure to factors controlling angiogenesis in the human term placenta. J ReprodFertil; 102(2): 447e50, (1994).

[27] ROLFO A., MANY A., RACANO A., TAL R., TAGLIAFERRO A. AND IETTA F.: Abnormalities in oxygen sensing define early and late onset preeclampsia as distinct pathologies. PLoS One; 5(10): e13288, (2010).

[28] ESCUDERO C., CELIS C., SAEZ T., SAN MARTIN S., VALENZUELA FJ AND AGUAYO C.: Increased placental angiogenesis in late and early onset pre-eclampsia is associated with differential activation of vascular endothelial growth factor receptor 2. Placenta; 35: 20715, (2014). 
[29] TSATSARIS V., GOFFIN F., MUNAUT C., BRICHANT J-F, PIGNON M-R AND NOEL A.: Overexpression of the soluble vascular endothelial growth factor receptor in preeclamptic patients: pathophysiological consequences. J ClinEndocrinolMetabo; 88: 5555-5563, (2003).

[30] CHUNG J-Y, SONG Y., WANG Y., MAGNESS RR AND ZHENG J.: Differential expression of vascular endothelial growth factor (VEGF), endocrine gland derived-VEGF, and VEGF receptors in human placentas from normal and preeclamptic pregnancies. J ClinEndocrinolMetab; 89: 24842490, (2004)

[31] GRINER PF, MAYEWSKI RJ, MUSHLIN AI, GREENLAND P.: Selection and interpretation of diagnostic tests and procedures. Annals of Internal Medicine 94:555-600, (1981). 